\title{
Factors Affecting Brand Identification and Loyalty in Online Community
}

\author{
Chieh-Min Chou \\ Graduate Institute of Management of Technology, Feng Chia University, Taichung, Taiwan. \\ Email: cmchou.fcu@gmail.com
}

Received October $22^{\text {nd }}, 2013$; revised November $22^{\text {nd }}$, 2013; accepted November $29^{\text {th }}, 2013$

Copyright (c) 2013 Chieh-Min Chou. This is an open access article distributed under the Creative Commons Attribution License, which permits unrestricted use, distribution, and reproduction in any medium, provided the original work is properly cited. In accordance of the Creative Commons Attribution License all Copyrights @ 2013 are reserved for SCIRP and the owner of the intellectual property Chieh-Min Chou. All Copyright (c) 2013 are guarded by law and by SCIRP as a guardian.

\begin{abstract}
This study explores the factors of online community characteristics which affect customer loyalty through the mediate effects of brand identification. By employing online questionnaire survey, hundreds of observations were collected from online brand communities in Taiwan for hypothetical model test. Research results show that brand loyalty is positively affected by stronger online brand identification which is enhanced by online community interactivity, satisfied customer relationship and platform quality. Based on the findings, this study suggests that online brand managers should focus on providing a rich interactive community environment for establishing satisfied customer relationship on a high quality platform to enhance brand identification thereby to earn customer's brand loyalty.
\end{abstract}

Keywords: Online Community; Brand Identification; Brand Loyalty

\section{Introduction}

The development of the Internet re-shapes the communication methods among people and companies. Before the World Wide Web appeared, consumers made purchase decision with information provided by television or radio advertising, outdoor billboards or word-of-mouth. Internet technologies enable companies to easily establish official website to provide consumers with product information in $24 \times 7$ manners. Although it broke the time and geographical limitations to approach consumers, the communication is still a one-way type. Until the web2.0 technologies are emerging, the interactive and collaborative online environment promotes many online communities established for information exchange and relationship building. Clever companies quickly found the potential and advantages of using online community to strengthen customer relationship and brand identification in order to enhance loyalty.

By analyzing the online brand community member behavior, this study observed consumers having different perception on community characteristics while interacting with company and other members, and that influences the generation of identity, shared value and relationship.
Companies now are facing a fuzzy industry demarcation and intense competition, which makes brand establishment become a necessity to maintain competitiveness. Two Taiwanese global PC manufacturers, ASUS and ACER for example, started to establish online community to strengthen brand identification and cultivate loyalty customers for improving profit structure. Brand equity is an invisible asset that increases the supply value of product or service, and this value belongs to companies and customers [1]. Nowadays many companies attempt to increase the brand value by excellent brand management practice which was realized on efficient and effective online community platform. It is a new phenomenon to set up online brand communities to promote and advertise products or services based on brand identification [2]. Many companies use online brand community to promote brand awareness and deliver brand, product and service information. In addition, the companies which establish long-term relationship with customers not only increase brand comprehension of potential customers, but also cultivate loyalty customers in this relationship process. For brand managers, it is a challenge to successfully deliver brand identity, impression and invisible value to customers for earning brand loy- 
alty in online brand community. Hence, the purpose of this paper is to explore the factors of online community characteristics which affect customer loyalty through the mediate effects of brand identification.

\section{Theoretical Background}

\subsection{Online Community}

People assemble together because of having common topic, interest or idea in human society. With Internet emergence, people interaction and contact have become tendency gradually in the online communities. Rheingold [3] defines online communities as Internet social aggregate in earliest period. A group of people who have emotional interaction and information exchange with each other will develop an interpersonal relationship network, and then online community is beginning to take shape.

Many scholars proposed the different definitions of online community. Armstrong and Hagel [4] defined that online community gathers people and let them trust each other from interaction continually. The human communication and information sharing by Internet and electronic media is a burgeoning society phenomenon [5]. When Internet users having common interest of emotion, they will exchange information and establish interpersonal relationship through participating discussion [6,7]. After interpersonal relationship being built, the people have common willing are forming Internet virtual society organization based on obligation and common objective [8]. Community members communicate with each other for obtainment common opinion, sharing common value, and developing continual relationship [9]. Armstrong and Hagel [4] proposed virtual community resources should include brand, customer relationship and content.

\subsection{Online Brand Community}

The online brand community is society-oriented that was derived from trade-oriented or economic-oriented community [9]. In community members exchange information, sharing product knowledge and supply problem solutions $[6,10]$. The online brand community comprises a group of people with brand knowledge and has no geographical limitations in the structure form [11]. More and more companies believe that online brand community providing great opportunities to communicate with customers, and access benefits of valuable ideas [12].

Online brand community can be categorized as two types, 1) consumer-initiated communities which are voluntarily built by their members and 2) company-initiated communities which are built by the company that owns the brand in order to establish a relationship with consumers and induce productive feedback from them [12]. The hosting type may be one of the most important fac- tors in classifying online communities because it results in different operating mechanisms [2,13]. In this paper, the company-initiated online brand communities which established by the companies to gather potential customers and building long-term relationship with existing customers were studied.

There are many different perspectives of the online brand community characteristic in literature. Lee and Kim [14] claimed that online brand community characteristic including information quality, service quality, rewards and member interaction. Jang et al. [12] believed that online brand community characteristic contains information quality, system quality, interaction, and rewards.

\subsection{Brand Identification}

Drawn from social identity theory, identification is essentially a perception of oneness with a group of people or an organization. To extend the concept, brand identification can be described as a person who perceives the degree to which one defines oneself by the same attributes held by the brand. Not all identifications involve the contractual parts of organizations, although they could be important drivers of member's behavior [15]. Good reputation can positively influence consumer's brand identification because individuals usually cognitively identify themselves with a winner. Corporate communication such as to provide customers with relevant information is another way to enhance identification [16]. Satisfied customer relationship can generate emotional and cognitive response to brand identification [17]. Consumers that have better relationship with brand-company and are satisfied with its products and services will be more likely to posit positive brand identification.

This study focused on online brand community characteristics which are possible to influence brand identification. Based on the literature review, this study concluded information quality, system quality, interactivity as focal factors and incorporate information quality and system quality into a generalized construct platform quality. This research also includes customer relationship which is antecedent of brand identification as one of focal factors to further understand the correlation in online context.

\subsection{Interactivity}

Either in real world or in cyberspace, the community members always interact with each other to deepen relationship and interchange message which significantly increase information flow [18]. Interactivity consists of man-machine interaction and inter-person interaction. The man-machine interaction refers to the users interact with the website or other information systems, and the 
inter-person interaction is user-centered that people interact with other users in cyberspace.

When interaction between information dispatcher and receiver is going frequently, the virtual community is deemed a society space, and the participants can gain the emotional support and information exchange [19]. The interaction between website and customers will influence customer loyalty in the virtual world [18,20]. If companies want to increase customer satisfaction and developing long-term relationship, they can regard website as communication channel that people contact directly. However, the website must have the mechanism of conversation and feedback. The more frequent interactivity of websites or communities offer, the higher trust and commitment of users will be built [21]. In the research of interactivity, Cooley [22] found that interactivity characteristic of website can increase interaction with customers and bring four advantages: benefit of company image, easy public opinion collection, customer desire reflection and enhancement company responsibility. Based on above perspective, the interactivity of online community can positively influence members' perception on brand prestige and understandings of corporate communication, hence to affect brand identification.

- H1: Online community interactivity positively influence brand identification.

\subsection{Platform Quality}

Online brand community members search and share information through Internet application systems. To provide excellent use experience, it is necessary to ensure the high information quality and system stability. Huizingh [23] pointed out that website information quality can be assessed by content and website design. Delone and Mclean [24] proposed information system success model that expect system quality and information quality will influence the user satisfaction. Sakaguchi and Frolick [25] pointed out high quality system quality should have integration function to integrate different information sources and satisfy user from different units. The user satisfaction is influenced by information system quality hence the platform should not only provide reliable information but update information to satisfy users [26].

Liu and Arnett [27] claimed high information quality can make user feel satisfaction. And the information of website can help customers reduce groping time and enhancement the value of information. Park and Kim [28] discovered information quality positively influencing relationship benefits. Customers' perception of online brand community platform quality will associate with the perceived reputation of brand, therefore the platform quality will also influence brand identification.
- H2: Online community platform quality positively influence brand identification.

\subsection{Customer Relationship}

Evan and Laskin [29] defined the customer relationship is customer-centric that company tends to maintain longterm business relationships with customers. Satisfied customer relationship brings lots of positive benefits to company such as higher profitability, customer loyalty, brand identification and more efficient business planning [30]. Customer relationship management is a philosophy of customer-oriented management that continually creates satisfied customers and maintains actively profitable long-term relationship.

In real world environment, customers can contact with company by face-to-face. But in virtual world, the online community has not geographical limitations and time limitations because customers can interact with company through Internet. Ryan [31] pointed out that the users satisfied obtainment of interpersonal relationship when participate in the virtual community which means online community provides interpersonal characteristics that user will feel satisfaction. Piskorski [32] pointed out that a successful community strategy should be able to help establishment of customer relationships. When companies began to build online brand communities, they not only concerned about the relationship between customer and company but among customers that strengthen the relationship between customers and products or services.

McAlexander et al. [33] proposed the concept of customer-centric brand community model which identified customer-product relationship, customer-brand relationship, customer-company relationship and customer-customer relationship. If customers and community establish higher degree of relationship, they will participate in the brand community easily and generate brand loyalty. These satisfied relationships will affect customer's identification of brand. Therefore this study posits a hypothesis:

- H3: Satisfied online community relationship positively influence brand identification.

\subsection{Brand Loyalty}

Brand loyalty means the customers are will to promote a company's products or services proactively and exhibit some loyal behaviors [34]. Brand loyalty can reduce marketing costs and strengthen the relationship between distributors and themselves that reduce threat of competitors. Literature indicates that a loyal customer will purchase more products and services and recommend them to others. Customers identifying with a brand community tend to be supportive and positively recommend the brand as well. Hence, 
- H4: Online community brand identification positively influence brand loyalty.

In addition, because satisfied online customer relationship was argued having positive impacts on brand loyalty by previous studies, this study also posit a hypothesis on the direct effect from satisfied customer relationship and brand loyalty.

- H5: Satisfied customer relationship positively influence brand loyalty.

The hypothesis research model is shown in Figure 1.

\section{Research Method and Data Analysis}

In order to test the research hypotheses, this study used an online survey method to collect data from an online sport community in Taiwan. The online sport community has more than four thousand active members, and this study sampled 500 members randomly from the full list. This research measured online brand community participants' perception on online community interactivity, satisfied customer relationship, platform quality, brand identification and brand loyalty in order to examine the influence paths. The respondents of this study all have experience of using online brand community. Total 281 filled questionnaires returned and 33 questionnaires were discarded because of a lack of integrity in some of the answers, which gives a final sample size of 248 observations for the data analysis. The sample profile is shown in Table 1.

\subsection{Reliability and Validity Analysis}

For instrument validation, a confirmatory factor analysis was performed to assess convergent and discriminate validity. The factor loadings of all measurement items ranged from 0.71 to 0.84 , which indicates that convergent validity is moderately acceptable (the details of the validation information are given in Table 2). This study also assessed construct reliability by calculating composite reliability to respective latent variables as suggested by Segars [35]. The estimates of composite reliability of latent variables ranged from 0.76 to 0.91 , significantly higher than the threshold of 0.7 suggested by Jöreskog \& Sörbom [36]. The Cronbach's $\alpha$ of all the latent variables

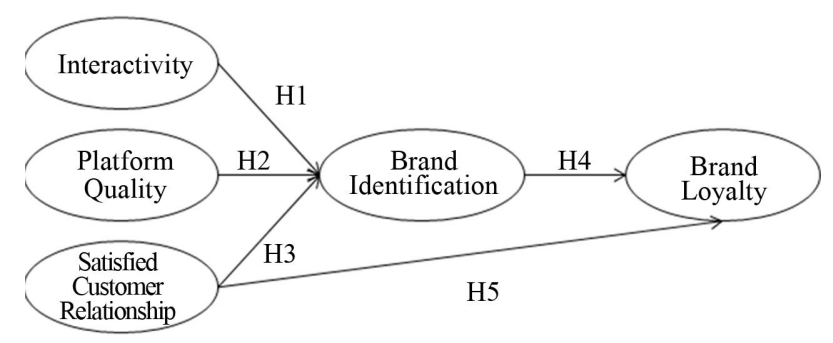

Figure 1. Conceptual framework.
Table 1. Demographic statistic.

\begin{tabular}{cccc}
\hline Attributes & Values & Frequency & Percentage \\
\hline \multirow{2}{*}{ Gender } & Male & 117 & 47.18 \\
& Female & 131 & 52.82 \\
& Under 20 & 22 & 8.87 \\
Age & 21 - 30 & 119 & 47.98 \\
& 31 - 40 & 96 & 38.71 \\
Education & Over 40 & 11 & 4.44 \\
& High school or & 26 & 10.48 \\
& below & 123 & 49.60 \\
& Griversity & 99 & 39.92 \\
Gime of participating & Under one month & 29 & 11.69 \\
the online brand & 1 - 3 months & 43 & 17.34 \\
community & 4 - 6 months & 51 & 20.56 \\
& 7 - 12 months & 44 & 17.74 \\
& 13 - 24 months & 41 & 16.53 \\
& Over 25 months & 40 & 16.13 \\
\hline
\end{tabular}

Note: The number of respondents $=248$.

Table 2. Factor loadings and cross-loadings.

\begin{tabular}{cccccc}
\hline Scale Items & ITA & PFQ & SCR & BI & BL \\
\hline ita1 & 0.84 & 0.58 & 0.42 & 0.35 & 0.35 \\
ita2 & 0.76 & 0.35 & 0.41 & 0.25 & 0.26 \\
ita3 & 0.73 & 0.41 & 0.38 & 0.30 & 0.28 \\
pfq1 & 0.27 & 0.73 & 0.41 & 0.37 & 0.36 \\
pfq2 & 0.38 & 0.79 & 0.37 & 0.36 & 0.30 \\
pfq3 & 0.53 & 0.78 & 0.47 & 0.40 & 0.37 \\
scr1 & 0.43 & 0.48 & 0.73 & 0.40 & 0.37 \\
scr2 & 0.37 & 0.46 & 0.71 & 0.44 & 0.45 \\
scr3 & 0.34 & 0.33 & 0.75 & 0.45 & 0.42 \\
bi1 & 0.25 & 0.38 & 0.49 & 0.81 & 0.57 \\
bi2 & 0.35 & 0.40 & 0.43 & 0.79 & 0.61 \\
bi3 & 0.28 & 0.40 & 0.40 & 0.78 & 0.61 \\
bl1 & 0.31 & 0.37 & 0.38 & 0.55 & 0.79 \\
bl2 & 0.23 & 0.30 & 0.37 & 0.56 & 0.78 \\
bl3 & 0.32 & 0.40 & 0.44 & 0.61 & 0.72 \\
\hline
\end{tabular}

Note: ITA: Interactivity; PFQ: Platform Quality; SCR: Satisfied Customer Relationship; BI: Brand Identification; BL: Brand Loyalty.

exceeded 0.7, which is the threshold suggested by Sharma [37].

Nevertheless, composite reliability cannot reflect the extent to which variance is captured by the constructs. 
Therefore, an average variance extracted (AVE) estimate is adopted to acquire this information. Fornell and Larcker [38] suggested that an acceptable AVE estimate should be higher than 0.5 for a construct's measure. In this study, all AVE estimates, with ranged from 0.54 to 0.61 , were above this cut-off value (detailed information of measurement reliability and validity are shown in Table 3).

\subsection{Model Fitness Testing}

In general, to evaluate the appropriateness of a structural model actually is to consider the fitness between actual data and theoretical model. Statistician developed lots of indices to assess model fitness such as Goodness of Fit Index (GFI), $\chi 2 / d f$, Adjusted Goodness of Fit Index (AGFI), Root Mean Square Residual (RMR), Normed Fit Index (NFI) and Comparative Fit Index (CFI) are common suggested $[39,40]$. Therefore, this study calculates all the indices in Table 4 for evaluation.

\subsection{Hypotheses Testing}

The study employed the structural equation model (SEM) method to test the research hypotheses using IBM soft-

Table 3. Correlation matrix, AVE and composite reliability.

\begin{tabular}{ccccccccc}
\hline & Cronbach's a & AVE & CR & ITA & PFQ & SCR & BI & BL \\
\hline ITA & 0.86 & 0.63 & 0.81 & 0.79 & & & & \\
PFQ & 0.92 & 0.65 & 0.85 & 0.59 & 0.81 & & & \\
SCR & 0.87 & 0.74 & 0.76 & 0.52 & 0.58 & 0.86 & & \\
BI & 0.84 & 0.61 & 0.91 & 0.39 & 0.49 & 0.59 & 0.78 & \\
BL & 0.82 & 0.71 & 0.89 & 0.39 & 0.47 & 0.56 & 0.77 & 0.84
\end{tabular}

Note: Square of root of AVE for each construct is shown in the diagonal of the correlation matrix. ITA: Interactivity; PFQ: Platform Quality; SCR: Satisfied Customer Relationship; BI: Brand Identification; BL: Brand Loyalty.

Table 4. The fitness indices between model and data.

\begin{tabular}{cccc}
\hline $\begin{array}{c}\text { Fitness } \\
\text { Indices }\end{array}$ & $\begin{array}{c}\text { Acceptance } \\
\text { Range }\end{array}$ & $\begin{array}{c}\text { Result of } \\
\text { model }\end{array}$ & $\begin{array}{c}\text { Meet } \\
\text { Requirement }\end{array}$ \\
\hline$\chi^{2} /$ df & $<3$ & 2.231 & Yes \\
GFI & $>0.9$ & 0.915 & Yes \\
AGFI & $>0.9$ & 0.901 & Yes \\
RMSEA & $<0.08$ & 0.071 & Yes \\
RMR & $<0.08$ & 0.035 & Yes \\
NFI & $>0.9$ & 0.869 & No \\
CFI & $>0.9$ & 0.922 & Yes \\
\hline
\end{tabular}

Note: $\chi 2$ df: Chi-Square Goodness of Fit; GFI: Goodness of Fit Index; AGFI: Adjusted Goodness of Fit Index; RMSEA: Root Mean Square Error of Approximation; RMR: Root Mean ware Amos 18. The test results show that satisfied customer relationship (SCR) and Interactivity (ITA) signifycantly influence a member's online brand identification (BI) at the significant level 0.01 ; online community platform quality (PFQ) influence a member's online brand identification (BI) at the significant level 0.05 , which support hypotheses H1, H2 and H3. The R2 of the online brand identification is 0.388 ; therefore, the overall online community factors can explain $38.8 \%$ variance of the online brand community member's brand identification. The path from the brand identification to brand loyalty (BL) is significant with a 0.01 level with a path coefficient 0.421 , hence hypothesis $\mathrm{H} 4$ is supported. Online community satisfied customer relationship (SCR) has significant positive impact on brand loyalty as well, which supports the H5. The R2 of brand loyalty is 0.227 , which indicates that online brand identification is a major mediating factor if a company wants to enhance brand loyalty in online brand community (the model test results are shown in Figure 2).

\section{Discussion}

\subsection{Theoretical and Managerial Implications}

Several theoretical implications can be drawn from these results. To our knowledge, the relationships between online community characteristics, brand identification and brand loyalty have not been discussed in the context of online communities in prior studies. The results of this study are a starting point for relevant research and establish basic understandings of consumer behavior in online brand communities. Furthermore, the mediating effect of brand identification in this theoretical model is reconfirmed in this study. This study also expanded on the model proposed by Kim et al. [9], which only examined the effects of online community characteristics on commitment. This research integrated prior studies for proposing a new model, the results of which contribute to our understanding of how to enhance brand loyalty through online brand community operation and management.

This study also has implications for practitioners and business managers. First, establishing an online brand community is an effective way to enhance a company's

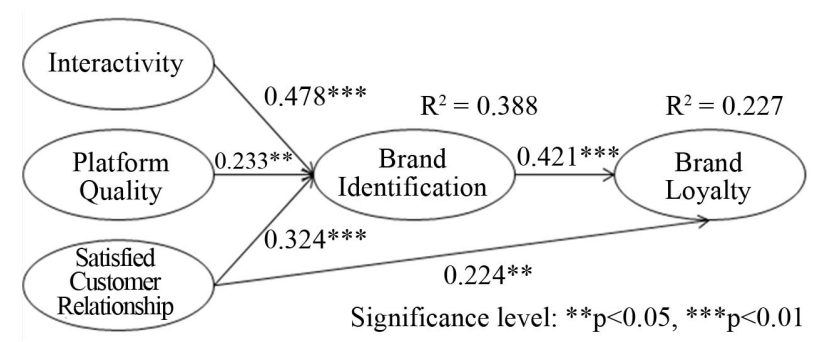

Figure 2. The model test results. 
brand loyalty as long as brand identification is strengthened. Second, to build satisfied customer relationship will not only increase brand identification but directly enhance brand loyalty. Third, although with lower influence coefficient, platform quality is still a significant factor to brand identification, which implies that online brand managers should be cautious when deciding which online platform over where they will set the brand community up.

\subsection{Limitations and Suggestions}

This study has certain limitations although steps were taken during both hypotheses development and data collection. First, despite the fact that this study referred to previous research for developing a measure scale of constructs, some original items were dropped because they did not pass the convergent validity test. Second, Third, although the index of broadband penetration in Taiwan ranks in the top six in the world, which implies that consumer behaviors in online communities are worth studying, cultural factors were not included in this study, and should be taken into account when applying the research results. Given the above limitations, further research should be cautious when explaining and applying the research results.

\section{Conclusions}

Internet and web 2.0 technologies materialize social network platforms, which allow people to easily establish identity and share values in virtual brand community. Through intensive interaction for corporate communication in cyber space, online brand community members can build satisfied relationships with the brand, product and company on a high quality online platform thereby increasing brand identification. With more and more companies establishing online brand communities to strengthen brand identification and brand loyalty, this study reveals and endorses the positive marketing value of online brand community management.

This hypothesis model test result exhibits that brand loyalty is significantly enhanced by stronger online brand identification, which in turn is strengthened by the following online community characteristics: interactivity, platform quality and satisfied customer relationship. The findings of the study, therefore, support all the hypotheses at statistical significant level 0.01 except for the $\mathrm{H} 2$ at significant level 0.05. Satisfied customer relationship has both positive effects on brand identification and brand loyalty.

\section{REFERENCES}

[1] D. A. Aaker, "The Value of Brand Equity," Journal of
Business Strategy, Vol. 13, No. 4, 1992, pp. 27-32. http://dx.doi.org/10.1108/eb039503

[2] A. Muniz and T. C. O’Guinn, "Brand community,” Journal of Consumer Research, Vol. 27, No. 4, 2001, pp. 412432. http://dx.doi.org/10.1086/319618

[3] H. Rheingold, "The Virtual Community: Homesteading on the Electronic Frontier," Addison-Wesley, New York, 1993.

[4] A. Armstrong and J. Hagel, "The Real Value of Online Community," Harvard Business Review, Vol. 74, No. 5, 1996, pp. 134-141.

[5] C. Romm, N. Plickin and R. Clarke, "Virtual Communities and Society: Toward an Integrative Three Phase Model," International Journal of Information Management, Vol. 17, No. 4, 1997, pp. 261-270. http://dx.doi.org/10.1016/S0268-4012(97)00004-2

[6] R. P. Bagozzi and U. M. Dholkia, "Open Source Software User Communities: A Study of Participation in Linux User Group,” Management Science, Vol. 52, No. 7, 2006, pp. 1099-1115. http://dx.doi.org/10.1287/mnsc.1060.0545

[7] A. M. Chang, P. K. Kannan and A. B. Whinston, "Electronic Communities as Intermediaries: The Issues and Economics," Proceeding of the 32nd Hawaii International Conference on System Sciences, Hawaii, 5-8 January 1999, pp. 1-10.

[8] F. T. Rothaermel and S. Sugiyamanb, "Virtual Internet Communities and Commercial Success: Individual and Community-Level Theory Grounded in the Atypical Case of Timezone.com,” Journal of Management, Vol. 27, No. 3, 2001, pp. 297-312.

[9] J. W. Kim, J. Choi, W. Qualls and K. Han, "It Take a Marketplace Community to Raise Brand Commitment: The Role of Online Communities,” Journal of Marketing Management, Vol. 24, No. 3-4, 2008, pp. 409-431. http://dx.doi.org/10.1362/026725708X306167

[10] A. Muniz and H. J. Schau, "Religiosity in the Abandoned Apple Newton Brand Community,” Journal of Consumer Research, Vol. 31, No. 4, 2005, pp. 737-747. http://dx.doi.org/10.1086/426607

[11] D. H. McKnight, V. Choudhury and C. Kacmar, "The Impact of Initial Consumer Trust on Intentions Transact with a Web Site: A Trust Building Mode,” The Journal of Strategic Information Systems, Vol. 11, No. 3, 2002, pp. 297-323. http://dx.doi.org/10.1016/S0963-8687(02)00020-3

[12] H. Jang, L. Olfman, I. Ko, J. Koh and K. Kim, “The Influence of Online Brand Community Characteristics on Community Commitment and Brand Loyalty,” International Journal of Electronic Commerce, Vol. 12, No. 3, 2008, pp. 57-80.

http://dx.doi.org/10.2753/JEC1086-4415120304

[13] L. L. Berry, "Relationship of Services: Growing Interest, Emerging Perspectives," Journal of the Academy of Marketing Science, Vol. 23, No. 4, 1995, pp. 236-245. http://dx.doi.org/10.1177/009207039502300402

[14] J. Y. Lee and Y. G. Kim, "Community Characteristics Effect Customer Commitment and Loyalty in the Online Consumer Community," Proceedings of the Korea Soci- 
ety of Management Information System Conference, Korea, 2005, pp. 841-848.

[15] S. Kuenzel and S. V. Halliday, "Investigating Antecedents and Consequences of Brand Identification,” Journal of Product \& Brand Management, Vol. 17, No. 5, 1992, pp. 293-304.

http://dx.doi.org/10.1108/10610420810896059

[16] A. Smidts, A. Pruyn and C. B. M. van Riel, "The Impact of Employee Communication and Perceived External Prestige on Organizational Identification," The Academy of Management Journal, Vol. 44, No. 5, 2001, pp. 10511062. http://dx.doi.org/10.2307/3069448

[17] D. Arnett, B. German and S. D. Hunt, "The Identity Salience Model of Relationship Marketing Success: The Case of Nonprofit Marketing," Journal of Marketing, Vol. 67, No. 2, 2003, pp. 89-105. http://dx.doi.org/10.1509/jmkg.67.2.89.18614

[18] R. T. Watson, S. Akselsen and L. F. Pitt, "Attractors: Building Mountains in the Flat Landscape of the World Wide Web,” California Management Review, Vol. 40, No. 2, 1998, pp. 36-43. http://dx.doi.org/10.2307/41165932

[19] G. Burnett, "Information Exchange in Virtual Communities: A Typology,” Information Research, Vol. 5, No. 4, 2000. http://informationr.net/ir/5-4/paper82.html

[20] J. Deighton, “The Future of Interactive Marketing," Harvard Business Review, Vol. 74, No. 11, 1996, pp. 151161.

[21] M. L. Kent, "Does Your Website Attract or repel Customers?” Public Relations Quarterly, Vol. 43, No. 4, 1998, pp. 31-33.

[22] T. Cooley, "Interactive Communication-Public Relations on the Web," Public Relations Quarterly, Vol. 43, No. 2, 1999, pp. 41.

[23] E. K. R. E. Huizingh, "The Content and Design of Web Sites: An Empirical Study,” Information \& Management, Vol. 37, No. 3, 2000, pp. 123-134. http://dx.doi.org/10.1016/S0378-7206(99)00044-0

[24] W. H. Delone and E. R. Mclean, "Information Systems Success: The Quest for the Dependent Variable," Information System Research, Vol. 3, No. 1, 1992, pp. 60-95. http://dx.doi.org/10.1287/isre.3.1.60

[25] T. Sakaguchi and M. N. Frolick, "A Review of the Data Warehousing Literature,” Journal of Data Warehousing, Vol. 2, No. 1, 1997, pp. 34-54.

[26] R. Y. Wang and D. M. Strong, "Beyond Accuracy: What Data Quality Means to Data Consumers," Journal of Management Information Systems, Vol. 12, No. 4, 1996, pp. 5-34.

[27] C. Liu and K. P. Arnett, "Exploring the Factors Associated with Web Site Success in the Context of Electronic Commerce," Information \& Management, Vol. 38, No. 1, 2000, pp. 22-34. http://dx.doi.org/10.1016/S0378-7206(00)00049-5
[28] C. H. Park and Y. G. Kim, "Identifying Key Factors Affecting Consumer Purchase Behavior in an Online Shopping Context," International Journal of Retail \& Distribution Management, Vol. 31, No. 1, 2003, pp. 16-29. http://dx.doi.org/10.1108/09590550310457818

[29] J. R. Evans and R. L. Laskin, "The Relationship Marketing Process: A Conceptualization and Application,” Industrial Marketing Management, Vol. 23, No. 5, 1994, pp. 439-454.

[30] M. Holmlund and S. Kock, "Relationship Marketing: The Importance of Customer-Perceived Service Quality in Retail Banking,” Service Industries Journal, Vol. 16, No. 3, 1996, pp. 287-304. http://dx.doi.org/10.1080/02642069600000029

[31] R. M. Ryan, "Psychological Needs and the Facilitation of Integrative Processes,” Journal of Personality, Vol. 63, No. 3, 1995, pp. 397-427. http://dx.doi.org/10.1111/j.1467-6494.1995.tb00501.x

[32] M. J. Piskorski, "Social Strategies That Work," Harvard Business Review, Vol. 89, No. 11, 2011, pp. 117-122.

[33] J. H. McAlexander, J. W. Schouten and H. F. Koening "Building Brand Community," Journal of Marketing, Vol. 66, No. 1, 2002, pp. 38-54. http://dx.doi.org/10.1509/jmkg.66.1.38.18451

[34] S. Kuenzel and S. V. Halliday, "The Chain of Effects from Reputation and Brand Personality Congruence to Brand Loyalty: The Role of Brand Identification," Journal of Targeting, Measurement and Analysis for Marketing, Vol. 18, No. 3-4, 2010, pp. 167-176. http://dx.doi.org/10.1057/jt.2010.15

[35] A. H. Segars, "Assessing the Unidimensionality of Measurement: A Paradigm and Illustration within the Context of Information Systems Research,” Omega, Vol. 25, No. 1, 1997, pp. 107-121. http://dx.doi.org/10.1016/S0305-0483(96)00051-5

[36] K. G. Jo“reskog and D. So“rbom, “LISREL 7 User’s Reference Guide,” Scientific Software, Chicago, 1989.

[37] S. Sharma, “Applied Multivariate Techniques,” John Wiley \& Sons Inc., New York, 1996.

[38] C. Fornell and D. F. Larcker, "Evaluating Structural Equation Models with Unobservable Variables and Measurement Error," Journal of Marketing Research, Vol. 18, No. 1, 1981, pp. 39-51. http://dx.doi.org/10.2307/3151312

[39] H. T. Chen and T. W. Lin, "How a 3D Tour Itinerary Promotion Affect Consumers' Intention to Purchase a Tour Product?” Information Technology Journal, Vol. 11, No. 10, 2012, pp. 1357-1368. http://dx.doi.org/10.3923/itj.2012.1357.1368

[40] J. F. Hair, R. E. Anderson, R. L. Tatham and W. G. Black, "Multivariate Data Analysis," Prentice Hall International, Upper Saddle River, 1998. 